\title{
GDP and beyond: Prosperity convergence in the countries of Western and Eastern Europe
}

\author{
MIRJANA GLIGORIĆ MATIĆ ${ }^{1 *}$ (D), \\ BILJANA JOVANOVIĆ GAVRILOVIĆ ${ }^{1}$ (i) and NENAD STANIŠIĆ ${ }^{2}$
}

${ }^{1}$ Faculty of Economics, University of Belgrade, Kamenička 6, Beograd 11000, Serbia

${ }^{2}$ Faculty of Economics, University of Kragujevac, Serbia

Received: December 27, 2018 • Revised manuscript received: August 5, 2019 • Accepted: November 2, 2019

(๔ 2020 Akadémiai Kiadó, Budapest

\begin{abstract}
After Second World War (WWII) a true evolution in understanding of economic development happened, which affected the ways of measuring prosperity, i.e. perceiving changes in people's welfare. Numerous indicators have been created, which go 'beyond GDP' and cover different aspects of development and wellbeing. The aim of this paper is to analyse prosperity convergence in 32 European countries with a composite indicator - Legatum Prosperity Index (LPI). LPI is more complete than other indicators used in convergence analysis and reflects multidimensional nature of modern development and prosperity. Our research of absolute beta convergence is based on cross-sectional and panel data. Results indicate the existence of convergence in the overall index and its constitutive parts - dimensions and pillars, with different convergence speed regarding LPI and its segments for the total sample of countries, as well as for the countries of Eastern and Western Europe.
\end{abstract}

\section{KEYWORDS}

GDP, sustainable development, Legatum Prosperity Index, convergence, European countries

\section{JEL CLASSIFICATION INDICES}

011, 047, 052, C33

\footnotetext{
"Corresponding author. E-mail: mirjana.gligoric@ekof.bg.ac.rs
} 


\section{INTRODUCTION}

During the last seven decades, the development debate went a long way - from dealing with economic growth, through being concerned about income distribution and environment, to focussing on human and especially sustainable development that is today widely accepted as a valid development paradigm. Simultaneously, the means of measuring prosperity, i.e. progress in human welfare also changed. Although GDP is an important indicator of countries' economic performance, other indicators that go 'beyond GDP' have been created to adjust, complement, or replace it, in order to express the complex nature of the modern development.

The composite welfare indices that combine a few different measures (where GDP can, but does not have to be included) into a single number deserve special attention. Thanks to plenitude of quantitative and qualitative information available today, it is possible to follow economic, social and ecological progress through multidimensional, complex indicators. Only aggregate indices that cover different aspects of sustainable development and welfare can rival GDP as an undoubtedly important but insufficient indicator for measuring prosperity. The most well-known composite welfare indices connected to sustainable development are: Human Development Index (HDI, UN Development Program 1990), Ecological Footprint (Wackernagel - Rees 1996), Living Planet Index (Loh et al. 1998), Happy Planet Index (Simms et al. 2006), Sustainable Society Index (Van de Kerk - Manuel 2008) and Social Progress Index (Porter et al. 2013).

Legatum Prosperity Index - LPI (Legatum Institute 2008), which is in the focus of this paper, also belongs to that group. LPI is a comprehensive indicator of economic progress and life quality, that is, material and nonmaterial welfare. This measure stresses the drivers and triggers of prosperity rather than its outcomes, which is why it can be considered as a kind of indicator of prosperity sustainability.

The objective of the paper is to analyse prosperity convergence through a comprehensive, multidimensional LPI indicator. That represents a step forward from existing research of the sort, based on the indicators that do not fully reflect the complex nature of modern development and prosperity. LPI is made of 9 pillars: Economic Quality, Business Environment, Health, Safety \& Security, Social Capital, Education, Governance, Personal Freedom and Natural Environment, which are classified into four groups: Economic, Social, Institutional and Environmental dimensions. ${ }^{1}$

Our empirical research is based on LPI data, as well as on all dimensions and pillars for the sample of 32 European countries for the 2007-2017 period. The convergence is analysed in two complementary ways: based on cross-sectional and panel data analysis. In both models the LPI growth rates or its pillars'/dimensions' growth rates are regressed against their initial level. If convergence exists, the initial value of LPI or their pillars/dimensions should be negatively related to their subsequent growth rates so that the countries with lower initial level will tend to develop faster than those with higher level. It is important to know whether the European countries recorded convergence in prosperity in the previous decade, as well as whether there was convergence in their particular segment - specific dimensions and pillars, i.e. which of the

${ }^{1}$ For detailed explanation about LPI and its parts see Gligorić et al. (2018). 
prosperity 'areas' have contributed to prosperity convergence in case of the European countries in the recent period.

Section 2 gives a review of some important papers related to the countries' convergence. In Section 3, we give detailed explanation of data, i.e. particularly important information about LPI and its constitutive parts, as well as clarification and specification of the empirical model used in the case of prosperity convergence analysis. In Section 4, we present the results of the research, in line with explanation and discussion. Section 5 contains the conclusion.

\section{LITERATURE REVIEW}

Concepts of beta and sigma convergence have been widely tested for decades. Many authors that examined absolute beta convergence and sigma convergence confirmed the existence of divergence among the world economies (e.g. Islam 2003; Milanovic 2005; Sala-i-Martin 1996). However, those studies that considered structural differences between countries mostly proved that convergence exists (e.g. Sala-i-Martin 1996) - i.e. that the less developed countries converge faster to their steady state than the more developed countries. Regarding empirical research on the sample of the European countries, income convergence is confirmed in specific cases/groups and periods (e.g. Stanišić 2012; Gligorić 2014; Recher - Kurnoga 2017).

In the research on development convergence, authors usually combined economic with social indicators. These studies mostly occurred in the last 10-15 years and many of them used additional indicators of well-being - separated or as a part of composite indices. Some of the initial research on convergence of well-being indicators examined convergence of life expectancy and education, calorie intake and infant mortality (Mazumdar 2003). Still, testing convergence in aggregate indices enables testing whether the countries are becoming more similar or different regarding to the quality of life. Several authors have tested convergence of human well-being by using data on Human Development Index (HDI).

Konya - Guisan (2008) and Konya (2011) empirically examined whether there is a convergence in terms of human development (using HDI data) over the previous three decades. Convergence was tested across large number of world countries as well as several groups (The Organisation for Economic Co-operation and Development (OECD) and European Union (EU)). They found that the rise in HDI was accompanied by a convergence, i.e. the countries with lower level of HDI experienced higher HDI increase than those with the higher level.

There are many other authors examining HDI convergence using different approaches. Cross-country analysis of HDI components, income, life expectancy, literacy and gross enrolment ratios, using database for 111 countries for the 1970-2005 period was conducted by Mayer-Foulkes (2010). Noorbakhsh (2006) also used HDI data and found weak absolute convergence over 1975-2002, conditional $\beta$-convergence and weak $\sigma$-convergence. Population weighted analysis provides support for polarization in the HDI amongst developing countries but a slight reduction in world inequality.

Jordá - Sarabia (2015a) re-examined the concept of beta-convergence in living standards across the countries for the period of 1980-2012. They used HDI to take into account economic as well as social aspects of development. Results obtained from the study implied the existence of beta and sigma convergence. Authors also applied a semiparametric specification of this process to the HDI and each of its intermediate indices and confirmed that convergence in human well- 
being is satisfactorily represented by the conventional linear specification, while the income and education indices show nonlinear patterns. Testing conditional convergence, they concluded that convergence speed of all indicators is higher, and the convergence process seems to be linear only for the health index.

Other authors broadly examined the subjects, e.g. how corruption affects the convergence process in human development across countries. Ortega et al. (2016), for the period of 19902012, analysed this using HDI, raw data on life expectancy at birth, mean years of schooling, GNI per capita and the Corruption Perceptions Index (CPI) in case of 69 countries clustered into three groups according to the level of the CPI. According to their results, convergence process across the clusters is not homogeneous and human development has different patterns of growth. Wellbeing is also measured for the Italian regions using specific indices and methods (e.g. Ferrara - Nisticò 2014; Di Berardino et al. 2015).

Still, HDI doesn't include some important aspects of wellbeing that should be incorporated in the index. Among them, two aspects are environment and institutions. Since measuring wellbeing is complex, LPI seems to be a very important indicator that represents multidimensional nature of it. LPI is relevant for empirical examination of prosperity convergence since it has data available for one decade for most countries enabling relevant empirical research. Literature overview suggests extensive usage of HDI as a development indicator, while LPI, according to our knowledge, was not previously used in the cross-country convergence analysis. LPI is more comprehensive than HDI and other similar composite indices, and convergence analysis of LPI and their constitution parts represent important contribution to the previous convergence literature.

\section{DATA AND METHODOLOGY}

\subsection{Data used in our empirical research}

We used the Legatum Institute data for Prosperity Index (LPI) as part of the empirical analysis. As we already mentioned above, LPI consists of nine components (pillars), and these pillars can further be grouped into four dimensions ${ }^{2}$ according to Table 1 :

LPI represents the measure of human progress and demonstrates how prosperity is created and how it changes in countries around the world (Legatum Institute 2016: 1). As a prosperity index, LPI is a combination of indicators of subjective wellbeing (i.e. measures of happiness) and economic indicators. The index at the same time indicates wealth (Economic Prosperity) and well-being (Social Well-being) of a country. Each of the pillars has about 12 variables, or to be more precise LPI has a total of 104 variables, of both objective ${ }^{3}$ and subjective data ${ }^{4}$. About $2 / 3$

\footnotetext{
${ }^{2}$ These 9 pillars are grouped into three dimensions by Legatum Institute: Economic, Social and Institutional (see Legatum Institute 2016: 8). Still, we think it would be analytically useful for the Natural Environment pillar to be separated from the Social dimension, and to constitute a distinct dimension instead. Therefore for Natural Environment pillar we formed the fourth dimension, which we call Environmental, and as far as remaining 8 pillars go, we kept the same division into 3 said dimensions (Table 1).

${ }^{3}$ Objective variables indicate material and institutional qualities in the form of falsifiable and 'hard' statistics.

${ }^{4}$ Subjective variables are self-assessed statements, acquired through various sorts of large-scale surveys. These variables include mental or emotional qualities felt by the population (Legatum Institute 2016: 12).
} 
Table 1. Nine components of LPI classified into four dimensions

\begin{tabular}{|l|c|c|c|c|}
\hline Dimensions & Economic & Social & Environmental & Institutional \\
\hline \multirow{4}{*}{$\begin{array}{c}\text { Components/ } \\
\text { Pillars }\end{array}$} & Economic quality & Health & $\begin{array}{c}\text { Natural } \\
\text { environment }\end{array}$ & $\begin{array}{c}\text { Governance personal } \\
\text { freedom }\end{array}$ \\
\cline { 2 - 3 } & $\begin{array}{c}\text { Business } \\
\text { environment }\end{array}$ & $\begin{array}{c}\text { Safety and } \\
\text { security }\end{array}$ & \\
\cline { 2 - 3 } & & Social capital & & \\
\cline { 2 - 3 } & & Education & & \\
\hline
\end{tabular}

Source: Authors' own representation.

of the mentioned variables are objective and 1/3 are subjective. Data for LPI are available from 2007 and are calculated and published for most of the world countries.

LPI ranks countries based on 'how well they execute things needed to achieve GDP growth (i.e. promoting economic competitiveness) and boost average subjective well-being or life satisfaction (i.e. promoting comparative liveability)' (Legatum Institute 2008: 10).

LPI was created with the intention to cover production per inhabitant, but also to focus on qualitative and distribution aspects of this income, as well as all aspects that define human happiness. Besides material wealth, the index encompasses social capital, health, equality of opportunity, environment, effective governance, human rights and liberties and overall quality of life. The index is also one of the few indices that have the environmental component included, which is, along with economic and social components, the main constituent of sustainable growth. LPI is, for that reason, more comprehensive, and thus, more relevant compared to the similar composite indices.

Variables in the LPI are expressed in different units of measurement: numbers of individuals, years, percentages and ordinal scales, etc. Because of that, they are first normalised using distance-to-frontier approach. For each variable, frontiers are defined as the best and worst cases, i.e. the highest and lowest values of the variable across the entire sample of the 149 world countries for which the LPI is calculated, and variable value for every country is compared and the country's relative position related to the designated frontiers is calculated. The distance from frontiers scores is multiplied by each variable weight. Each of 104 variables is assigned one of the four weights: $0.5,1,1.5$ and 2, according to the level of importance it has in affecting prosperity, and then, summed up to get the score for each pillar. LPI is then computed as an arithmetic mean, by putting equal weights on each pillar score. Therefore, this structure of LPI, i.e. LPI's additive form implies perfect substitution across the pillars. ${ }^{5}$

Related to this LPI construction approach, sensitivity analysis is performed to test the impact on the Index's scores and rankings. The actual weighting approach is compared with (a) equally weighted variables and (b) a randomised weighting approach derived using Monte Carlo randomisation simulations is also tested.

\footnotetext{
${ }^{5} \mathrm{~A}$ review of this issue in case of HDI can be found in Klugman et al. (2011). Also, these concepts are well presented in Decancq - Neumann (2016).
} 
When all variables are weighted equally, many countries experience minor changes in their overall prosperity score and ranking. Also, using 1,000 randomly generated different weights, for most countries the median ranking obtained from the simulations corresponds to the LPI ranking. Therefore, both approaches indicate important conclusion for robustness of empirical results obtained using LPI: 'that the scores and rankings in the Prosperity Index are overwhelmingly affected by variations in the variables themselves, with weights attached to the variables playing a secondary role'. ${ }^{6}$

We have used panel analysis to test whether there is an absolute $\beta$-convergence in prosperity on the sample of 32 European countries by using:

(a) LPI data,

(b) data for the four LPI dimensions and

(c) data for the nine LPI components/pillars.

Since so far, no empirical research on prosperity convergence of the European countries was conducted using LPI, in this work we examined prosperity progress of the EU states (28 countries) together with 4 Western Balkan countries, ${ }^{7}$ i.e. 32 countries in total.

According to LPI Report 2017, all countries in the world, covered by the analysis are divided into seven regions. Two of them are Eastern and Western Europe (Legatum Institute, 2017c: 31). The Western European countries are summarised in Table 2. ${ }^{8}$ Therefore, we estimated a convergence equation for the total sample of countries (32), as well as for the two groups of countries: Western Europe (17 countries) and Eastern Europe (15 countries).

Even though LPI is an index comprised of drivers of prosperity rather than index of prosperity outcomes (Legatum Institute 2008: 10), we rate convergence within drivers of prosperity, integrated into indices form and observed individually as well as grouped into four dimensions. Accordingly, in this paper we use different approach compared to the previous research concerning the convergence analysis - because our goal is to examine the state and dynamics of the core of the difference in wellbeing between countries, as well as to elaborate upon that through the insight into state and dynamics of different kinds of drivers.

\subsection{Specification of the empirical model}

If convergence exists, the initial value of the following indices: LPI, their pillars/components and dimensions should be negatively related to their subsequent growth rates so that the countries with lower initial level will tend to grow faster than those countries with higher level; otherwise there is a divergence.

We analysed convergence in two complementary ways: based on the cross-sectional data and panel data. In both models the LPI and its pillars'/dimensions' growth rates are regressed against

\footnotetext{
${ }^{6}$ For details of sensitivity analysis, see Legatum Prosperity Index 2016 - Methodology Review (Legatum Institute 2016: 20-21) and see Legatum Prosperity Index 2017 - Methodology Review (Legatum Institute 2017a: 20-21).

${ }^{7}$ North Macedonia, Serbia, Montenegro and Albania are the candidate countries.

${ }^{8}$ From 20 countries belonging Western Europe group according to Legatum (see Legatum Institute 2017c: p. 32) we excluded non-EU countries: Norway, Switzerland and Iceland. From 22 countries belonging Legatum's Eastern Europe group (Legatum Institute 2017c: p. 38) we took out seven countries: Georgia, Belarus, Armenia, Moldova, Russia, Azerbaijan and Ukraine. That is because we wanted to examine only EU and EU candidate countries.
} 
Table 2. List of European countries in the sample and their global LPI rank

\begin{tabular}{|c|c|}
\hline Western Europe & Global LPI rank \\
\hline Finland & 3 \\
\hline Sweden & 5 \\
\hline Netherlands & 6 \\
\hline Denmark & 7 \\
\hline UK & 10 \\
\hline Germany & 11 \\
\hline Ireland & 12 \\
\hline Luxembourg & 14 \\
\hline Austria & 15 \\
\hline Belgium & 16 \\
\hline France & 19 \\
\hline Spain & 20 \\
\hline Malta & 22 \\
\hline Portugal & 25 \\
\hline Italy & 30 \\
\hline Cyprus & 31 \\
\hline Greece & 49 \\
\hline Eastern Europe & Global LPI rank \\
\hline Slovenia & 21 \\
\hline Czech R. & 26 \\
\hline Estonia & 27 \\
\hline Poland & 32 \\
\hline Slovakia & 35 \\
\hline Latvia & 37 \\
\hline Lithuania & 41 \\
\hline Croatia & 43 \\
\hline Hungary & 45 \\
\hline Romania & 46 \\
\hline Bulgaria & 51 \\
\hline North Macedonia & 56 \\
\hline Serbia & 58 \\
\hline Montenegro & 65 \\
\hline Albania & 75 \\
\hline
\end{tabular}

Source: Authors' own representation. 
their initial level. The difference between the two approaches is in the fact that in the crosssectional analysis the average growth rates of indices over the whole observed period (20072017) are regressed against their value in the first observed year (2007), compared to the panel approach where the growth rates of indices in one year are regressed against the indices values in the previous year.

The equation that relates the average growth rate with the initial level is derived in Barro Sala-i-Martin (2003):

$$
1 / T \log (y(i, T) / y(i, 0))=a-\left[\left(1-e^{-\beta t}\right) / T\right] \log (y(i, 0))+w_{i 0}, T,
$$

where $y_{(i, T)}$ and $y_{(i, 0)}$ represent the LPI or some LPI component/dimension in country $i$ in the final and initial year, $T$ is the length of the period of observation, $a$ is a constant term, $\beta$ is the coefficient of the speed of convergence, and $w$ is the error term.

To verify the convergence hypothesis based on the cross-sectional data, we estimate the regression in the form:

$$
1 / T \log (y(i, T) / y(i, 0))=\alpha_{0}+\alpha_{1} \log y(i, 0)+e(i),
$$

where $\log y_{(T)}$ and $\log y_{(0)}$ are the natural logarithms of indices value in country $i$ in the last and the first year of the period under analysis, respectively; $\alpha_{0}$ is a constant; $e_{(i)}$ is the error term; and $T$ indicates the duration of the period.

The dependent variables are the average annual growth rates of overall LPI/LPI component/ LPI dimension. Negative coefficient for the explanatory variable, i.e. log of the initial values of respective indices, implies the presence of convergence.

In the second approach, with panel data, convergence is tested based on the following regression equation: ${ }^{9}$

$$
\log (y(i, T))-\log (y(i, T-1))=\alpha_{0}+\alpha_{1} \log (y(i, T-1))+e(i, t) .
$$

\section{RESULTS AND DISCUSSION}

Table 3 presents the summary statistics (average values and standard deviations) for overall LPI, its four dimensions and nine components (pillars). At the dimension level, the highest average value is recorded in the case of institutional dimension, followed by social, natural environment and economic dimensions.

Fig. 1 presents the scatterplot of log of initial LPI (in 2007) and average annual growth rate over the period of 2007-2017 for all 32 observed countries. Visible downslope trend, i.e. the indirect relation between initial LPI values and its growth rates, implies the existence of convergence.

The results of the estimation of regression Eq. (2) for overall LPI and its four dimensions are given in Table 4. Negative coefficient on initial overall LPI level implies the convergence over the observed country sample and time. Convergence is also observed in the case of three LPI

\footnotetext{
${ }^{9}$ Panel analysis are done using the Fixed Effect (FE) and Random Effect (RE) approaches. The Hausman test is used to choose between the FE and RE. The results of the Hausman test (presented in Appendix 1) suggest that the FE model is preferable to that of the RE. Therefore, only the FE model results will be presented in the following section.
} 
Table 3. Summary statistics

\begin{tabular}{|c|c|c|c|c|}
\hline LPI & Dimension & Component & Average & St. deviation \\
\hline \multicolumn{3}{|c|}{ Overall LPI } & 66.76 & 7.19 \\
\hline & \multicolumn{2}{|c|}{ Economic } & 63.45 & 8.78 \\
\hline & & Economic quality & 70.39 & 8.10 \\
\hline & & Business environment & 56.51 & 10.00 \\
\hline & \multicolumn{2}{|c|}{ Institutional } & 69.41 & 10.32 \\
\hline & & Governance & 64.55 & 12.85 \\
\hline & & Personal freedom & 74.27 & 8.64 \\
\hline & \multicolumn{2}{|c|}{ Social } & 68.29 & 5.70 \\
\hline & & Education & 67.71 & 7.02 \\
\hline & & Health & 76.06 & 4.48 \\
\hline & & Safety and security & 76.67 & 4.47 \\
\hline & & Social capital & 52.72 & 8.87 \\
\hline & \multicolumn{2}{|c|}{ Natural environment } & 61.96 & 7.71 \\
\hline
\end{tabular}

Source: Authors' own calculation.

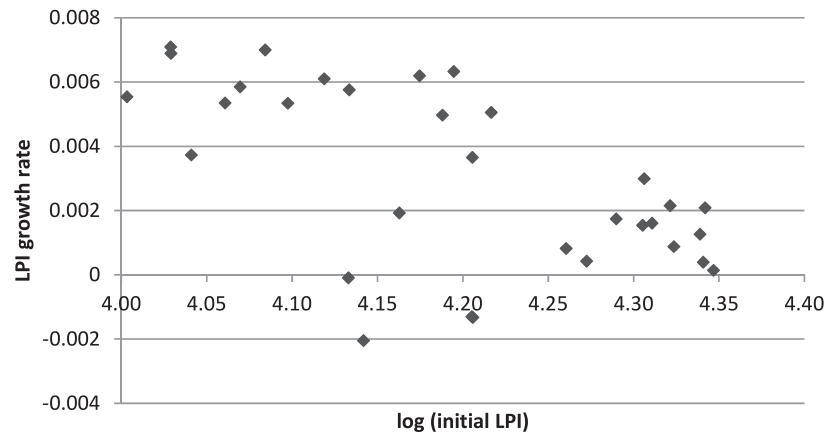

Fig. 1. Scatter plot of LPI values and its growth rates

Source: Authors' own calculations and representation.

dimensions: economic, social and environmental. On the other hand, there was no convergence in the case of institutional dimension of LPI. The speed of the convergence was the highest in the case of economic dimension.

Table 5 presents the results of the cross-sectional regression analysis of convergence of nine LPI pillars. Significant and negative coefficients indicate the convergence process in the case of 6 LPI pillars: Economic quality, Business Environment, Governance, Safety and Security, Social 
Table 4. Cross-sectional regression results for overall LPI and its four dimensions

\begin{tabular}{|c|c|c|c|c|}
\hline Dependent variable & Independent variable & Coefficients & \multicolumn{2}{|c|}{ Model summary } \\
\hline \multirow[t]{4}{*}{ Overall LPI growth } & Ln initial LPI & $-0.015^{* * *}$ & $F$ stat. & $18.47 * * *$ \\
\hline & (Std. Err.) & $(0.003)$ & & \\
\hline & Cons. & $0.068 * * *$ & $R^{2}$ & 0.39 \\
\hline & (Std. Err.) & $(0.015)$ & & \\
\hline \multirow[t]{4}{*}{ Economic dimension growth } & Ln initial ECON & $-0.035^{* * *}$ & $F$ stat. & $60.17 * * *$ \\
\hline & (Std. Err.) & $(0.004)$ & & \\
\hline & Cons. & $0.148 * * *$ & $R^{2}$ & 0.67 \\
\hline & (Std. Err.) & $(0.018)$ & & \\
\hline \multirow[t]{4}{*}{ Institutional dimension growth } & Ln initial INST & -0.001 & $F$ stat. & 0.08 \\
\hline & (Std. Err.) & $(0.005)$ & & \\
\hline & Cons. & 0.008 & $R^{2}$ & 0.03 \\
\hline & (Std. Err.) & $(0.024)$ & & \\
\hline \multirow[t]{4}{*}{ Social dimension growth } & Ln initial SOC & $-0.016 * * *$ & $F$ stat. & $16.44 * * *$ \\
\hline & (Std. Err.) & $(0.004)$ & & \\
\hline & Cons. & $0.071 * * *$ & $R^{2}$ & 0.33 \\
\hline & (Std. Err.) & $(0.017)$ & & \\
\hline \multirow[t]{4}{*}{ Environmental dimension growth } & Ln initial ENVI & $-0.026 * *$ & $F$ stat. & $5.91 * *$ \\
\hline & (Std. Err.) & $(0.010)$ & & \\
\hline & Cons. & $0.118^{* *}$ & $R^{2}$ & 0.16 \\
\hline & (Std. Err.) & $(0.044)$ & & \\
\hline
\end{tabular}

Notes: $* * *$ Significance at $1 \%, * * 5 \%$ level, respectively.

Source: Authors' own calculation.

Capital and Natural Environment, while there was no convergence in the case of Personal Freedom, Education and Health components of the LPI. The highest rate of convergence was achieved in the case of Business Environment, followed by Social Capital, Natural Environment and Economic Quality.

The results of the panel Fixed Effect (FE) estimations are presented in Table 6. The convergence is tested for overall LPI and its four dimensions (economic, institutional, social and environmental), for all 32 observed countries, as well as for the Western European and Eastern European countries separately.

In all three estimations (for Europe, Western Europe and Eastern Europe), the coefficient on initial LPI indices (overall LPI and its four dimensions) is significant and negative, indicating a 
Table 5. Cross-sectional regression results for nine LPI pillars

\begin{tabular}{|c|c|c|c|c|}
\hline Dependent variable & Independent variable & Coefficients & Mode & summary \\
\hline Economic quality component growth & Ln_econ & $-0.025 * * *$ & $F$ stat. & $18.15^{* * *}$ \\
\hline & (Std. Err.) & $(0.006)$ & & \\
\hline & Cons. & $0.107 * * *$ & $R^{2}$ & 0.37 \\
\hline & (Std. Err.) & $(0.025)$ & & \\
\hline Business environment component growth & Ln_busi & $-0.044 * * *$ & $F$ stat. & $94.23 * * *$ \\
\hline & (Std. Err.) & $(0.004)$ & & \\
\hline & Cons. & $0.0190 * * *$ & $R^{2}$ & 0.75 \\
\hline & (Std. Err.) & $(0.018)$ & & \\
\hline Governance component growth & Ln_gove & $-0.015^{* * *}$ & F stat. & $8.20 * * *$ \\
\hline & (Std. Err.) & $(0.005)$ & & \\
\hline & Cons. & $0.065^{* * *}$ & $R^{2}$ & 0.21 \\
\hline & (Std. Err.) & $(0.022)$ & & \\
\hline Personal freedom component growth & Ln_pers & 0.010 & $F$ stat. & 1.30 \\
\hline & (Std. Err.) & $(0.009)$ & & \\
\hline & Cons. & -0.042 & $R^{2}$ & 0.04 \\
\hline & (Std. Err.) & $(0.039)$ & & \\
\hline Education component growth & Ln_educ & -0.002 & $F$ stat. & 0.56 \\
\hline & (Std. Err.) & $(0.003)$ & & \\
\hline & Cons. & 0.014 & $R^{2}$ & 0.01 \\
\hline & (Std. Err.) & $(0.016)$ & & \\
\hline Health component growth & Ln_heal & -0.010 & $F$ stat. & 2.35 \\
\hline & (Std. Err.) & $(0.006)$ & & \\
\hline & Cons. & 0.046 & $R^{2}$ & 0.07 \\
\hline & (Std. Err.) & $(0.029)$ & & \\
\hline Safety and security component growth & Ln_safe & $-0.022 * *$ & $F$ stat. & $4.69 * *$ \\
\hline & (Std. Err.) & $(0.010)$ & & \\
\hline & Cons. & $0.100 * *$ & $R^{2}$ & 0.13 \\
\hline & (Std. Err.) & $(0.045)$ & & \\
\hline
\end{tabular}

(continued) 
Table 5. Continued

\begin{tabular}{|l|c|c|c|c|}
\hline Dependent variable & Independent variable & Coefficients & \multicolumn{2}{|c|}{ Model summary } \\
\hline Social capital component growth & Ln_soci & $-0.031^{* * *}$ & $F$ stat. & $70.51^{* * *}$ \\
\cline { 2 - 5 } & (Std. Err.) & $(0.003)$ & & \\
\cline { 2 - 5 } & Cons. & $0.125^{* * *}$ & $R^{2}$ & 0.70 \\
\cline { 2 - 5 } & (Std. Err.) & $(0.014)$ & & \\
\hline Natural environment component growth & Ln_envi & $-0.026^{* *}$ & $F$ stat. & $5.91^{* *}$ \\
\cline { 2 - 5 } & (Std. Err.) & $(0.010)$ & & \\
\cline { 2 - 5 } & Cons. & $0.118^{* *}$ & $R^{2}$ & 0.16 \\
\cline { 2 - 5 } & (Std. Err.) & $(0.044)$ & & \\
\cline { 2 - 5 } & & & & \\
\hline
\end{tabular}

Notes: $* * *$ Significance at $1 \%, * * 5 \%$ level, respectively.

Source: Authors' own calculations.

case of convergence. The rate of convergence was significantly higher within the group of the Western European countries than in the group of the Eastern European countries for overall LPI, as well as for all four dimensions (economic, social, environmental and institutional).

The highest rate of convergence within the whole sample was achieved in case of social dimension, followed by institutional, environmental and economic dimensions. Among the Western European countries, the highest rate of convergence was also achieved in case of social dimension, followed by institutional, environmental and economic dimensions. Among the Eastern European countries, the fastest convergence was in case of institutional dimension, then environmental, economic and social dimensions.

Table 7 presents the results of panel FE estimations for all 9 LPI pillars. Significant and negative coefficients indicate the convergence process in case of all nine LPI pillars and all three estimated models. Compared between two country groups, the convergence was higher among the Western European countries in case of Business Environment, Education, Safety and Security, Social Capital and Natural Environment pillars, while the Eastern European countries had a fastest convergence in case of Economic Quality, Governance, Personal Freedom and Health pillars.

The highest rate of convergence among 32 observed European countries in the 2007-2017 period was achieved in the case of Social Capital pillar, followed by Health, Personal Freedom, Safety and Security, Education, Natural Environment, Governance, Business Environment and Economic Quality pillars.

Among the Western European countries, the highest rate of convergence was achieved in the case of Social Capital. That is followed by, respectively (in order from highest to lowest convergence coefficient): Safety and Security, Education, Health, Natural Environment, Personal Freedom, Business Environment, Governance and Economic Quality.

Within the sample of the Eastern European countries, the convergence was the strongest in the case of Health pillar, then Personal Freedom, Social Capital and Education, followed by Governance, Economic Quality, Safety and Security, Natural Environment and Business Environment. 
Table 6. Panel regression results for overall LPI and its four dimensions

\begin{tabular}{|c|c|c|c|c|}
\hline & & $\begin{array}{c}\text { Total } \\
\text { (Model 1) }\end{array}$ & $\begin{array}{l}\text { Western Europe } \\
\text { (Model 2) }\end{array}$ & $\begin{array}{c}\text { Eastern Europe } \\
\text { (Model 3) }\end{array}$ \\
\hline \multirow[t]{7}{*}{ Overall LPI } & InLPI & $-0.205^{* * *}$ & $-0.317^{* * *}$ & $-0.159 * * *$ \\
\hline & (Std. Err.) & $(0.036)$ & $(0.061)$ & $(0.045)$ \\
\hline & Cons. & $0.866 * * *$ & $1.361 * * *$ & $0.663 * * *$ \\
\hline & (Std. Err.) & $(0.151)$ & $(0.265)$ & $(0.189)$ \\
\hline & No. & 320 & 170 & 150 \\
\hline & F stat. & $32.28 * * *$ & $26.33^{* * *}$ & $12.08 * * *$ \\
\hline & $\mathrm{R}^{2}$ & 0.11 & 0.14 & 0.08 \\
\hline \multirow[t]{7}{*}{ Economic dimension } & Ln_ECON & $-0.262 * * *$ & $-0.291 * * *$ & $-0.252 * * *$ \\
\hline & (Std. Err.) & $(0.032)$ & $(0.055)$ & $(0.043)$ \\
\hline & Cons. & $1.093 * * *$ & $1.229 * * *$ & $1.033 * * *$ \\
\hline & (Std. Err.) & $(0.136)$ & $(0.233)$ & $(0.177)$ \\
\hline & No. & 320 & 170 & 150 \\
\hline & F stat. & $63.54 * * *$ & $27.65^{* * *}$ & $33.38^{* * *}$ \\
\hline & $\mathrm{R}^{2}$ & 0.18 & 0.15 & 0.19 \\
\hline \multirow[t]{7}{*}{ Social dimension } & Ln_SOC & $-0.324 * * *$ & $-0.478 * * *$ & $-0.235^{* * *}$ \\
\hline & (Std. Err.) & $(0.045)$ & $(0.067)$ & $(0.061)$ \\
\hline & Cons. & $1.374 * * *$ & $2.055 * * *$ & $0.985^{* * *}$ \\
\hline & (Std. Err.) & $(0.192)$ & $(0.290)$ & $(0.258)$ \\
\hline & No. & 320 & 170 & 150 \\
\hline & F stat. & $50.72 * * *$ & $49.86 * * *$ & $14.48 * * *$ \\
\hline & $\mathrm{R}^{2}$ & 0.15 & 0.24 & 0.09 \\
\hline \multirow[t]{7}{*}{ Environmental dimension } & Ln_ENVI & $-0.276 * * *$ & $-0.312 * * *$ & $-0.254 * * *$ \\
\hline & (Std. Err.) & $(0.030)$ & $(0.047)$ & $(0.039)$ \\
\hline & Cons. & $1.168 * * *$ & $1.333^{* * *}$ & $1.063 * * *$ \\
\hline & (Std. Err.) & $(0.126)$ & $(0.200)$ & $(0.163)$ \\
\hline & No. & 320 & 170 & 150 \\
\hline & F stat. & $84.41 * * *$ & $43.77^{* * *}$ & $41.30 * * *$ \\
\hline & $\mathrm{R}^{2}$ & 0.22 & 0.22 & 0.23 \\
\hline \multirow[t]{7}{*}{ Institutional dimension } & Ln_INST & $-0.303 * * *$ & $-0.322 * * *$ & $-0.288 * * *$ \\
\hline & (Std. Err.) & $(0.043)$ & $(0.058)$ & $(0.065)$ \\
\hline & Cons. & $1.286 * * *$ & $1.398 * * *$ & $1.184 * * *$ \\
\hline & (Std. Err.) & $(0.184)$ & $(0.253)$ & $(0.268)$ \\
\hline & No. & 320 & 170 & 150 \\
\hline & F stat. & $48.30 * * *$ & $30.45^{* * *}$ & $19.39 * * *$ \\
\hline & $R^{2}$ & 0.14 & 0.16 & 0.12 \\
\hline
\end{tabular}

Note: $* * *$ Significance at $1 \%$ level.

Source: Authors' own calculations. 
Table 7. Panel regression results for nine LPI pillars

\begin{tabular}{|c|c|c|c|c|}
\hline LPI pillars & & Total (1) & Western Europe (2) & Eastern Europe (3) \\
\hline \multirow[t]{7}{*}{ Economic quality } & Ln_econ & $-0.234 * * *$ & $-0.209 * * *$ & $-0.280 * * *$ \\
\hline & (Std. Err.) & $(0.025)$ & $(0.033)$ & $(0.060)$ \\
\hline & Cons. & $0.990 * * *$ & $0.894^{* * *}$ & $1.164^{* * *}$ \\
\hline & (Std. Err.) & $(0.109)$ & $(0.142)$ & $(0.2487)$ \\
\hline & No. & 320 & 170 & 150 \\
\hline & F stat. & $81.91 * * *$ & $39.57 * * *$ & $21.90 * * *$ \\
\hline & $\mathrm{R}^{2} \_\mathrm{a}$ & 0.18 & 0.20 & 0.14 \\
\hline \multirow[t]{7}{*}{ Business environment } & Ln_busi & $-0.258 * * *$ & $-0.309 * * *$ & $-0.250 * * *$ \\
\hline & (Std. Err.) & $(0.026)$ & $(0.061)$ & $(0.032)$ \\
\hline & Cons. & $1.062 * * *$ & $1.286^{* * *}$ & $1.012 * * *$ \\
\hline & (Std. Err.) & $(0.108)$ & $(0.255)$ & $(0.128)$ \\
\hline & No. & 320 & 170 & 150 \\
\hline & F stat. & $94.94 * * *$ & $25.27 * * *$ & $59.69 * * *$ \\
\hline & $R^{2} \_a$ & 0.25 & 0.14 & 0.31 \\
\hline \multirow[t]{7}{*}{ Governance } & Ln_gove & $-0.263 * * *$ & $-0.224 * * *$ & $-0.296 * * *$ \\
\hline & (Std. Err.) & $(0.035)$ & $(0.045)$ & $(0.054)$ \\
\hline & Cons. & $1.093 * * *$ & $0.956 * * *$ & $1.188^{* * *}$ \\
\hline & (Std. Err.) & $(0.148)$ & $(0.196)$ & $(0.219)$ \\
\hline & No. & 320 & 170 & 150 \\
\hline & F stat. & $54.27 * * *$ & $23.86 * * *$ & $29.13 * * *$ \\
\hline & $R_{-}^{2} a$ & 0.16 & 0.14 & 0.18 \\
\hline \multirow[t]{7}{*}{ Personal freedom } & Ln_pers & $-0.353 * * *$ & $-0.309 * * *$ & $-0.415^{* * *}$ \\
\hline & (Std. Err.) & $(0.048)$ & $(0.062)$ & $(0.077)$ \\
\hline & Cons. & $1.523 * * *$ & $1.360 * * *$ & $1.748^{* * *}$ \\
\hline & (Std. Err.) & $(0.209)$ & $(0.272)$ & $(0.326)$ \\
\hline & No. & 320 & 170 & 150 \\
\hline & F stat. & $52.69 * * *$ & $24.81 * * *$ & $28.66 * * *$ \\
\hline & $R_{-}^{2} a$ & 0.16 & 0.14 & 0.18 \\
\hline \multirow[t]{3}{*}{ Education } & Ln_educ & $-0.333 * * *$ & $-0.344 * * *$ & $-0.321 * * *$ \\
\hline & (Std. Err.) & $(0.044)$ & $(0.063)$ & $(0.062)$ \\
\hline & Cons. & $1.408 * * *$ & $1.472 * * *$ & $1.339 * * *$ \\
\hline
\end{tabular}


Table 7. Continued

\begin{tabular}{|c|c|c|c|c|}
\hline LPI pillars & & Total (1) & Western Europe (2) & Eastern Europe (3) \\
\hline & (Std. Err.) & $(0.188)$ & $(0.269)$ & $(0.261)$ \\
\hline & No. & 320 & 170 & 150 \\
\hline & F stat. & $55.96 * * *$ & $29.79 * * *$ & $26.04 * * *$ \\
\hline & $R^{2} \_a$ & 0.16 & 0.17 & 0.16 \\
\hline \multirow[t]{7}{*}{ Health } & Ln_heal & $-0.373 * * *$ & $-0.336 * * *$ & $-0.437 * * *$ \\
\hline & (Std. Err.) & $(0.046)$ & $(0.058)$ & $(0.076)$ \\
\hline & Cons. & $1.623 * * *$ & $1.474 * * *$ & $1.879 * * *$ \\
\hline & (Std. Err.) & $(0.202)$ & $(0.257)$ & $(0.330)$ \\
\hline & No. & 320 & 170 & 150 \\
\hline & F stat. & $63.95^{* * *}$ & $32.69 * * *$ & $32.37 * * *$ \\
\hline & $\mathrm{R}^{2}{ }_{\mathrm{a}}$ & 0.18 & 0.18 & 0.19 \\
\hline \multirow[t]{7}{*}{ Safety and security } & Ln_safe & $-0.351 * * *$ & $-0.484 * * *$ & $-0.266 * * *$ \\
\hline & (Std. Err.) & $(0.049)$ & $(0.071)$ & $(0.069)$ \\
\hline & Cons. & $1.534 * * *$ & $2.129 * * *$ & $1.149 * * *$ \\
\hline & (Std. Err.) & $(0.215)$ & $(0.312)$ & $(0.297)$ \\
\hline & No. & 320 & 170 & 150 \\
\hline & F stat. & $50.61 * * *$ & $46.47 * * *$ & $14.80 * * *$ \\
\hline & $\mathrm{R}^{2} \mathrm{a}^{\mathrm{a}}$ & 0.15 & 0.23 & 0.10 \\
\hline \multirow[t]{7}{*}{ Social capital } & Ln_soci & $-0.440 * * *$ & $-0.648 * * *$ & $-0.342 * * *$ \\
\hline & (Std. Err.) & $(0.052)$ & $(0.0740)$ & $(0.073)$ \\
\hline & Cons. & $1.746 * * *$ & $2.641 * * *$ & $1.320 * * *$ \\
\hline & (Std. Err.) & $(0.206)$ & $(0.301)$ & $(0.281)$ \\
\hline & No. & 320 & 170 & 150 \\
\hline & F stat. & $71.48 * * *$ & $76.66 * * *$ & $21.80 * * *$ \\
\hline & $\mathrm{R}^{2} \_\mathrm{a}$ & 0.20 & 0.34 & 0.14 \\
\hline \multirow[t]{5}{*}{ Natural environment } & Ln_envi & $-0.276^{* * *}$ & $-0.312 * * *$ & $-0.254 * * *$ \\
\hline & (Std. Err.) & $(0.030)$ & $(0.047)$ & $(0.039)$ \\
\hline & Cons. & $1.168^{* * *}$ & $1.333 * * *$ & $1.063 * * *$ \\
\hline & (Std. Err.) & $(0.1260)$ & $(0.200)$ & $(0.163)$ \\
\hline & No. & 320 & 170 & 150 \\
\hline
\end{tabular}


Table 7. Continued

\begin{tabular}{|l|c|c|c|c|}
\hline LPI pillars & & Total (1) & Western Europe (2) & Eastern Europe (3) \\
\hline & F stat. & $84.41^{* * *}$ & $43.77^{* * *}$ & $41.30^{* * *}$ \\
\hline & $\mathrm{R}^{2} \_\mathrm{a}$ & 0.22 & 0.22 & 0.23 \\
\hline
\end{tabular}

Note: $* * *$ Significance at $1 \%$ level.

Source: Authors' own calculation.

Since LPI represents a comprehensive, multidimensional indicator that consists of nine pillars and four dimensions, we think that our results are complementary (in the case of number of indicator's components, sample of countries, observed period, methodology, etc.) to the existing results in the literature of the sort (based on some other development indicators and their components - such as research that focuses on HDI (e.g. Mayer-Foulkes 2010; Jordá - Sarabia 2015a, 2015b)), therefore adding knowledge to the broader research of convergence that goes 'beyond GDP'.

From the methodological point of view, it could be noted that the panel regressions showed higher coefficients for independent variables (initial prosperity indices) compared to the equivalent crosssectional regressions, indicating higher speed of convergence. Main reason for this could be the fact that panel data take explicit account of individual-specific heterogeneity. Comparative advantage of panel regression is that panel data is better suited than cross-sectional data for studying the dynamics of change, which is the case in this research. On the other hand, cross-sectional analysis has advantage over panel analysis, bearing in mind that the panel items are influenced by the short-term (year-toyear) variability which can be very high. For that reason, coefficients of determination are higher, and the standard errors are lower in the cross-sectional regressions. Given these differences, the two methods used in this paper (cross-sectional and panel) are used as complementary methods that combined could provide more insights into the prosperity convergence in Europe.

\section{CONCLUSION}

The evolution of understanding national economic development, which marked the period after Second World War (WWII), influenced the means of measuring prosperity of a country, that is, the progress achieved in the area of human welfare. Better progress measures, focused on welfare of present but also future generations instead of on production, are not only welcome, but needed. Activities in that area have recently been intensified, especially when it comes to creating complex composite indices, including LPI.

Our research is based on the LPI data, their pillars and dimensions for the sample of 32 European countries, as well as for two narrower samples: Eastern and Western Europe for the period of 2007-2017. The absolute beta convergence is analysed by regressing the LPI growth rates or its pillars'/dimensions' growth rates against their initial level using the cross-sectional and panel analysis. Obtained results indicate that the countries with lower level of prosperity (overall LPI) recorded faster increase of LPI than those with higher level. Therefore, the European countries noted convergence in prosperity in the previous decade.

We used two complementary methods, cross-sectional and panel regressions, showed slightly different results, with the convergence confirmed more often and with higher speed in the case of panel analysis. 
At the level of four prosperity dimensions, the cross-sectional regression results showed that the convergence was present in the case of economic, environmental and social dimensions. While convergence was not registered in the case of institutional dimension of prosperity index using the cross-sectional data sample, the panel regression finds convergence in the case of all four LPI dimensions. Analysing prosperity dimensions, the panel data indicates that the highest rate of convergence within the whole sample of the European countries and within Western Europe was achieved in the case of social dimension, followed by institutional, environmental and economic dimensions. The Eastern European countries had the fastest convergence in the case of institutional dimension, followed by environmental, economic and social dimensions.

Regarding LPI components/pillars convergence, convergence was confirmed within six out of nine components of LPI in the case of cross-sectional data sample, while it was confirmed in all nine components in the case of panel data sample. The highest rate among the countries in the sample was achieved in the case of Social Capital and Health pillars. On the other hand, the slowest convergence was in the case of Business Environment and Economic Quality pillars. Within the sample of the Western European countries, the highest rate of convergence was achieved in Social Capital and Safety and Security pillars, while the lowest rates of convergence were indicated in the case of Governance and Economic Quality pillars. Among the Eastern European countries, the convergence was the strongest in Health and Personal Freedom, and the weakest in the case of Natural Environment and Business Environment pillars.

Our results are complementary to the existing results in the literature of the sort, therefore adding knowledge to broader research of convergence that goes 'beyond GDP'. By providing the picture of prosperity convergence in Europe at the level of four prosperity dimensions and its nine components, the results of this research could be useful for policy makers in order to enhance specifically aimed effort to obtain further economic and social cohesion in Europe, i.e. to reduce disparities between countries.

Further research could focus on other types of convergence, including sigma and conditional beta convergence, while this paper focuses only on absolute beta convergence, However, the convergence might be influenced by technology, population growth and human capital, which might differ between countries. Further models, thus, should include relevant control variables to investigate the presence of conditional convergence.

Wewould like to mention that the previous analysis, in the context of wider discussion on inequality in the modern world (most often seen through the prism of GDP or wealth) points to the optimistic conclusion that the differences in prosperity between the chosen European countries, seen as a whole or on the regional level, have decreased during the 2007-2017 period. This decrease in inequality was spurred by faster prosperity growth in initially less prosperous countries. By growing faster, these countries have narrowed the gap between their level of prosperity and higher-level characteristic for more progressive countries. The most important drivers for narrowing differences in prosperity have been identified and they are somewhat different in the countries of Eastern and Western Europe, which indicates certain specificities in paving their road towards prosperity.

\section{ACKNOWLEDGEMENTS}

This research was supported by the Ministry of Education, Science and Technological Development of the Republic of Serbia (Grant No. 179005, 179065, III-46001 and III-47005). 


\section{REFERENCES}

Barro, R. J. - Sala-i-Martin, X. (2003): Economic Growth. Cambridge, MA: MIT Press Books.

Decanq, K. - Neumann, D. (2016): Does the Choice of Well-Being Measure Matter Empirically? In: Adler,

D. - Fleurbaey, M. (eds): The Oxford Handbook of Well-Being and Public Policy. OUP, pp. 553-587.

Di Berardino, C. - Mauro, G. - Quaglione, D. - Sarra, A. (2016): Industrial Districts and Socio-Economic Well-Being: An Investigation on the Italian Provinces Disparities. Social Indicators Research, 129(1): 337-363.

Ferrara, A. R. - Nistico, R. (2013): Well-Being Indicators and Convergence across Italian Regions. Applied Research in Quality of Life, 8(1): 15-44.

Gligorić, M. (2014): Paths of Income Convergence Between Country Pairs within Europe. Economic Annals, 59(201): 123-155.

Gligorić, M. - Jovanović Gavrilović, B. - Savić, Lj (2018): Prosperity Index as a Measure of Wellbeing in European Union and Western Balkan Countries. Teme, XLII(4): 1253-1275.

Islam, N. (2003): What Have We Learnt from the Convergence Debate? Journal of Economic Surveys, 17(3): 309-362.

Jordá, V. - Sarabia, J. M. (2015a): International Convergence in Well-Being Indicators. Social Indicators Research, 120(1): 1-27.

Jordá, V. - Sarabia, J. M. (2015b): Well-Being Distribution in the Globalization Era: 30 Years of Convergence. Applied Research in Quality of Life, 10(1): 123-140.

Klugman, J. - Rodríguez, F. - Choi, H. J. (2011): The HDI 2010: New Controversies, Old Critiques. The Journal of Economic Inequality, 9(2): 249-288.

Konya, L. (2011): New Panel Data Evidence of Human Development Convergence from 1975 to 2005. Global Business and Economics Review, 13(1): 57-70.

Konya, L. - Guisan, M. C. (2008): What does the Human Development Index Tell us about Convergence? Applied Econometrics and International Development, 8(1): 19-40.

Legatum Institute (2008): The 2008 Legatum Prosperity Index Report - Methodology, Data and Findings. http://www.OECD.Org/Site/Progresskorea/Globalproject/43414628.pdf.

Legatum Institute (2016): Legatum Prosperity Index 2016 - Methodological Report. http://www.Prosperity. Com/Application/Files/1914/7819/5146/Legatum_Prosperity_Index_Methodology_Report.pdf.

Legatum Institute (2017 a): Legatum Prosperity Index 2017 - Methodological Report. http://Prosperitysite.

S3-Accelerate.Amazonaws.Com/9615/1186/6075/Legatum_Prosperity_Index_2017_Methodology_

Report.pdf.

Legatum Institute (2017 b): Prosperity Rankings: Full Data Set. http://www.Prosperity.Com/About/Resources. Legatum Institute (2017 c): The Legatum Prosperity Index. Legatum Institute. https://www.prosperity.com/ download_file/view_inline/3479.

Loh, J. (ed.) (1998): Living Planet Report 1998: Overconsumption is Driving the Rapid Decline of the World's Natural Environments. Gland, Switzerland: World Wildlife Fund for Nature.

Mayer-Foulkes, D. (2010): Divergences and Convergences in Human Development. Human Development Research Paper, No. 2010/20, UNDP.

Mazumdar, K. (2003): Do Standards of Living Converge? A Cross-Country Study. Social Indicators Research, 64(1): 29-50.

Milanovic, B. (2005): Worlds Apart: Measuring International and Global Inequality. Princeton: Princeton University Press. 
Noorbakhsh, F. (2006): International Convergence or Higher Inequality in Human Development? Evidence for 1975-2002. WIDER Research Paper, No. 2006/15.

Ortega, B. - Casquero, A. - Sanjuán, J. (2016): Corruption and Convergence in Human Development: Evidence from 69 Countries during 1990-2012. Social Indicators Research, 127(2): 691-719.

Porter, M. E. - Stern, S. - Artavia Loría, R. (2013): Social Progress Index 2013. Washington, DC.: Social Progress Imperative.

Recher, V. - Kurnoga, N. (2017): European Integration Perspectives from Cohesion to Divergence? Acta Oeconomica, 67(2): 195-214.

Sala-i-Martin, X. (1996): The Classical Approach to Convergence Analysis. The Economic Journal, 106(437): 1019-1033.

Simms, A. - Marks, N. - Abdallah, S. - Thompson, S. (2006): The Happy Planet Index. London: New Economics Foundation.

Stanišić, N. (2012): The Effects of the Economic Crisis on Income Convergence in the European Union. Acta Oeconomica, 62(2): 161-182.

United Nations Development Program (UNDP) (1990): Human Development Report. New York: Oxford University Press.

Van de Kerk, G. - Manuel, A. R. (2008): A Comprehensive Index for a Sustainable Society: The SSI -The Sustainable Society Index. Ecological Economics, 66(2-3): 228-242.

Wackernagel, M. - Rees, W. E. (1996): Our Ecological Footprint: Reducing Human Impact on the Earth. Gabriola Island, BC: New Society Publishers.

\section{APPENDIX}

Table A1: Hausman test results

\begin{tabular}{|l|c|c|}
\hline & Chi squared & Prob (Chi_sqr) \\
\hline Overall LPI & 27.34 & 0.000 \\
\hline Economic dimension & 45.46 & 0.000 \\
\hline Institutional dimension & 48.11 & 0.000 \\
\hline Social dimension & 45.32 & 0.000 \\
\hline Environmental dimension & 71.64 & 0.000 \\
\hline
\end{tabular}

Note: Results for 9 pillars suggest the same - that the FE model is preferable to that of RE. They are not presented in table due to limited space but are available from the authors upon request. 